\title{
SOCIAL REPRESENTATIONS OF COLLEGE APPLICANTS: (RE)CONSTRUCTING THE STEREOTYPE OF ACCOUNTING PROFESSIONALS
}

\author{
Gilberto José Miranda ${ }^{1}$ \\ Edvalda Araújo Leal ${ }^{2}$ \\ Cíntia Rodrigues de Oliveira Medeiros ${ }^{3}$ \\ Sirlei Lemes ${ }^{4}$
}

\begin{abstract}
Professional stereotypes are the result of the social representations constructed in a determined social and cultural context that orient people and social groups in the understanding of professional roles. That is, stereotypes can influence the choice of a profession, notably among teenagers. In the case of Accounting professionals, the prevailing social representations do not attribute a very attractive image to them. The traditional stereotype of an accountant is characterized predominantly as a conservative and relatively inflexible male. Since social representations are constructed in determined historical contexts, stereotypes also change depending on them. This study examines the social representations of college applicants, for the purpose of analyzing their opinions regarding the Accounting profession, to compare them with the traditional stereotype of these professionals. For this purpose, a descriptive survey was conducted among 807 prospective college students who had just finished taking their entrance exams, using the photo-questionnaire tested and validated by Azevedo (2010). The aim was to find out whether the social representation of these college applicants corresponds to the traditional image of the accountant, in the current context of change that permeates accountancy. The results indicate a possible shift in the stereotype, based on the social representations of the respondents. In other words, the accounting professionals are not negatively stereotyped by the college applicants regarding the variables investigated in this study, as follows:"creativity","dedication to studies", "teamwork","communication","leadership", "risk propensity" and "ethics". These representations obtained at the moment of choosing a major, and hence a likely profession, are important, since these college applicants constitute a new generation, whose vision of the world differs from that of previous generations and indicate a congruence with the changes that have occurred in Accounting, the market and society in general.
\end{abstract}

Keywords: Accounting profession. Social representations. Stereotypes. College applicants.

\footnotetext{
1 E-mail: gilbertojm@facic.ufu.br. Doutor em Controladoria e Contabilidade (FEA-USP). Universidade Federal de Uberlândia.

2 E-mail: edvalda@facic.ufu.br. Doutora em Administração (FGV-SP). Universidade Federal de Uberlândia.

3 E-mail: cintia@fagen.ufu.br. Doutora em Administração (FGV-SP). Universidade Federal de Uberlândia.

3 4 E-mail: sirlemes@uol.com.br. Doutora em Controladoria e Contabilidade (FEA-USP). Universidade Federal de Uberlândia.

- DOI: http://dx.doi.org/10.14392/asaa.2015080102

- Artigo recebido em 02/09/2014. Revisōes requeridas em 11/04/2015. Aprovado em 17/04/2015.

- O trabalho foi apresentado no VII Congresso da ANPCONT (2013) e recebeu o Prêmio de melhor trabalho da linha "Educação e Pesquisa".
} 


\title{
REPRESENTACÕES SOCIAIS DE VESTIBULANDOS: (RE) CONSTRUINDO O์ ESTEREÓTIPO DOS PROFISSIONAIS DA CONTABILIDADE
}

\begin{abstract}
Resumo: Estereótipos profissionais são frutos de representações sociais construídas em determinado contexto social e cultural que orientam sujeitos e grupos sociais na compreensão sobre o desempenho de papéis profissionais. Ou seja, os estereótipos podem interferir também na escolha da profissão, notadamente quando tais escolhas são efetuadas ainda na adolescência. No caso dos profissionais de contabilidade, as representações sociais atribuem a esses uma imagem não muito atrativa. $O$ estereótipo tradicional do contador tem sido caracterizado, predominantemente, por um indivíduo do sexo masculino, conservador e pouco flexível. Como as representações sociais são construídas em determinados contextos históricos, os estereótipos também se modificam, dependendo do contexto. Nesta pesquisa, lança-se o olhar para as representações sociais de vestibulandos, com o propósito de conhecer as suas opiniões acerca do profissional contábil, de forma a compará-las com o estereótipo tradicional desses profissionais. Para alcançar o objetivo estabelecido, realizou-se uma pesquisa descritiva com 807 vestibulandos, utilizando-se o fotoquestionário testado e validado por Azevedo (2010) como instrumento para a coleta de dados. Essa intenção de pesquisa origina-se do questionamento se a representação social do público pesquisado corresponde à imagem tradicional desse profissional no atual contexto permeado de mudanças na Contabilidade. Os resultados apontam uma possível quebra no estereótipo acerca dos profissionais de contabilidade, a partir das representações sociais dos vestibulandos pesquisados. Em outras palavras, os profissionais de contabilidade não são estereotipados negativamente pelos candidatos universitários em relação às variáveis investigadas neste estudo:


risco"e "ética". Essas representações sociais obtidas no momento de escolha profissional são importantes, visto que esses vestibulandos constituem uma nova geração, cuja visão de mundo difere de épocas anteriores, indicando uma congruência com as mudanças ocorridas na própria contabilidade, no mercado e na sociedade em geral.
\end{abstract}

Palavras-chave: Profissão Contábil. Representações Sociais. Estereótipos. Vestibulandos.

\section{INTRODUCTION}

ocial representations are forms of practical knowledge; therefore, they refer to the common sense knowledge. Unlike the theories of knowledge that constitute sets of verifiable and coherent statements, social representations are socially built and shared, because they are manifestations of social constructions subject to the determinations of the socio and historical context (Spink, 1993).

Therefore, social representations on the reality are constructed and reconstructed by the subjects who interpret everyday reality, constructing and reconstructing over and over the common sense knowledge, the form by which people perceive the events and information that will guide their conduct and communication. So that, regarding professionals' social representation do not occur exclusively in specific formation courses, but also in various spheres, including those courses that precede them. 
The professional stereotype, which is a fruit of social representations built in particular social and cultural context can influence subject and as a consequence the social groups. We can affirm that the stereotype does influence the professional choice of people who prepare themselves to enter higher education. Like any professional, social representations attach to accountant a stereotype that has been disseminated over time, influencing social interpretations on the role he plays in labor market. In the seventies, the stereotype of this professional showed him as a cold, aloof and impersonal human being (Decoster, Rhode, 1971). Several studies were carried out on the stereotype of accountant professional and, in a general way, his image has not been very attractive, because stereotyping suggests that his labor is irrelevant and the professionals are boring, methodical, inflexible and tedious ones (Friedman \& Lyne, 2001, Hunt, Falgiani \& Intrieri, 2004, Jeacle, 2008, Carnegie \& Napier, 2010).

International studies overall point the traditional stereotype of Accounting professional, characterized as a male, conservative and inflexible person (Hunt et al., 2004, Dimnik \& Felton, 2006). These characteristics are justified by the social and historical context which this profession was created in, when the accountant developed the role of "bookkeeper" in a course almost exclusively for men.

In Brazil, the vision of "bookkeeper" is also present. Pires, Ott and Damacena (2009), for example, analyzed some texts of job offers and they identified a demand for a profile in which"the predominant idea is that the accountant is a technical professional which therefore makes it sought to play closer to those functions that characterize the 'bookkeeper' and not the 'business partner' described in the literature" (Pires, Ott \& Damacena, 2009, pp. 181).

However, in the contemporary context, the Accounting professional not only plays a relevant role in the company but he also is a manager and an architect of financial information data bank, which are fundamental to the decision making process inside and outside the organizations. Social and cultural changes impact the companies functioning that, in turn, influence the performance of professional roles. Considering that social representations are (re)constructed along the years, we posed the following search question: do social representations made by college applicants on the accountant confirm the traditional stereotype of this professional?

In order to know the social representations of college applicants on Accounting professional as well as comparing it to the professional's stereotype, we carried out a descriptive search with 807 college applicants, using as search instrument the photo questionnaire tested and validated by Azevedo (2010). We aimed to identify whether the social representation of the subjects corresponds to the traditional conception on this professional.

The results showed that the accounting professionals are not negatively stereotyped by the college applicants regarding the variables investigated in this study, as follows: "creativity", "dedication to studies", "teamwork", "communication", "leadership", "risk propensity" and "ethics".

We hope this study can contribute to evidence the accountant stereotype in the college applicants' perception. They are young people who are choosing their professional qualification. The results of this study were compared to correlated ones and they allowed us to revisit the accountant image as well as analyzing the achieved advances regarding the social representation on Accounting field. 
This paper has five sections, besides this introduction. The first and the second sections present the literature review on social representation theory and stereotypes, relevant aspects regarding the accountant training as well previous studies on this professional's stereotype. The third section describes the methodology and the fourth one presents the results. Afterwards, we close the paper with the conclusions.

\section{SOCIAL REPRESENTATIONS AS A KIND OF KNOWLEDGE: (RE CONSTRUCTION OF PROFESSIONAL STEREOTYPES}

The social representations area interests all the human sciences (Jodelet, 2001), because it is related to social interactions. They are conceived as" a kind of social elaborated and shared knowledge which has a practical purpose and contributes to the construction of a common reality to a social group" (Jodelet, 2001, pp. 8) and guide the individual on identifying and solving arising problems, becoming, then, in a form of expressing reality. As Moscovici (2004), Jodelet (2001) believes that it is not the knowledge generated through evidence and proof, but rather that knowledge constructed outside the formal rigor of science, which is shared within the same society.

As they belong to common sense knowledge, far from being a primitive version and failure of scientific knowledge (Moscovici, 2004), social representations are a form of knowledge that has a logic that operates under separate rules (Grize, 2001). This logic is defended by Berger and Luckmann (1987), who state that reality social construction is a fruit of human action in society and reflects that men know as real in everyday life, guiding their practices and their decisions and actions.

According to Moscovici (1978, pp. 28), social representation is a "knowledge organized corpus and one of the psychic activities by which men make intelligible the physical and social realities, fall within a group or a daily link exchanges, and release the power of their imagination". The constructed knowledge defines meanings, and therefore affects the subject's judgment on situations he faces. Spink (1993) points out that the representation is constructed by the social subject. This author, as Moscovici (1978), affirms that the social subject is not "only a product of social determinations nor as independent producer, because the representations are always contextualized constructions as a result of the conditions where they arise and circulate in" (Spink, 1993, pp. 303).

Neither is it a view of the subject, warning Moscovici (1978), as this may be a position in respect of a dispute. The social representations are presented as a 'network' of ideas, metaphors and images, more or less freely interconnected and therefore more mobile and fluid than theories" (Moscovici, 2004, pp. 210). So, social representations are located at the interface in the individual and collective, being constructed in the mediation of individuals and groups with the world through language and communication, according to the historical, social and cultural context (Spink, 1993).

Constructed and (re)constructed social representations result in images and cognitive patterns which lead to simplified perceptions and generally with no matrix, which are the stereotypes. According to Hall (1997), stereotyping is a mechanism used in maintaining social and symbolic order, because the stereotype establishes a boundary between "normal" and "deviant", "normal" and "pathological", the "acceptable" and "unacceptable", which "belongs" and who "do not belong", between "we" and "they ". This author considers that the stereotypes reduce, essencialize, naturalize and correct 'differences', excluding everything that does not fit and generate prejudiced attitudes. Prejudice and stigma are similar processes, but prejudice and stigma are similar processes, but while the first is related to a social 
process derived from the domination and exploitation, the second concerns to the application of social norms (Phelan, Link \& Dovidio, 2008).

In that same vein, Goffman (1988) outlines the concept of stigma as a relationship between attribute and stereotype, distinguishing normal and stigmatized people. The first develop the attributes of the latter, which are transformed into normative expectations, requirements presented in a rigorous fashion. These requirements reduce the stigmatized to a spoiled and diminished person, because stigmatization is "the process or the situation of the individual who is incapable of full social acceptance" (Goffman, 1988, pp. 7). Therefore, the author uses the word stigma concerning to a deeply discrediting attribute in a relationship language, and not to the attribute itself. Goffman believes that the stigmatized has two identities: (1) the real one (the attributes the person proves to have) and (2) the virtual one (requirements and character inputs regarding what the stranger should be). Stigmas can be perpetuated during times. Many stigmas exist only in a given historical, social and cultural context, and others are modified according to the historical context. Ainlay, Bercker and Colman (1986) state that the stigma perception is modified among the social contexts.

\section{ACCOUNTING PROFESSIONALS AND THEIR STEREOTYPES}

Social representations on professional profiles are cognitive schemas that act as lenses that filter out information on the characteristics of a group. These schemes result in a pattern that will be used for future judgments, decisions, inferences and predictions. Accounting professionals play an important role in society and, as with other professions, they are stereotyped by the predominant profile in the professional group. When the stereotype is negative, such as professionals considered as boring, methodic, inflexible and tedious as in Accounting area(Friedman \& Lyne, 2001, Hunt et al., 2004, Jeacle, 2008, Carnegie \& Napier, 2010), it can influence attitudes of devaluating the class, inhibiting possible choices of future professionals, and influence the construction of their identity.

Several studiers searched social representations and the accountant stereotype from the seventies. DeCoster and Rhode (1971) considered that there was a discrepancy between the accountant popular stereotypes as well as between this aimed image and the real one. So that they studied personality characteristics of these professionals, comparing them to other professional groups and they did not find evidences which could support the literature spread stereotype which that portrayed a"negatively stereotyped as cold, indifferent, not sociable, submissive, superficial, weak, passive and insensitive professional" (Decoster \& Rhode, 1971, pp. 661).

More than three decades later, the stereotype associated to the accountants, in general researches, is that of a "conservative accountant" (Albu et al., 2011), an image that still persists as Wells (2010), despite the changes in the role played by accountants and in business environment.

The study carried out by Hunt et al. (2004) identified negative stereotypes on accounting profession, pointing out that the accountants are focused on tax assessment, mathematical calculations, are extremely detailed and didn't have leadership skills. Moreover, the subjects do not recognize their profession as ethic and dynamic for business. Convergent with these authors, other research showed that, as the profession, the public surveyed think that this involves repetitive and systematic activities related to calculations and taxes (Parker, 2000, Freedman \& Lyne, 2001, Dminik \& Felton, 2006, Schlee et al., 2007). Other scholars have pointed out that accountant image perceived by students, professionals 
or managers (Dimmik \& Felton, 2006, Carnegie \& Napier, 2010) portrays a male, conservative, antisocial, inflexible, methodical, cautious and highly quantitative person.

In Brazil, researches on social representations and stereotypes of the Accounting profession began in the early 2000s, identifying, in general, a reproduction of traditional stereotyping. For example, Dias (2003), aiming to evaluate the collective imaginary on Accounting profession, found that for most respondents, the counter is only the professional who takes care of the Accounting books in the company. $\mathrm{He}$ is a professional whom to spend a lot of money with, because it is mandatory to the professional who understands income tax and who knows how to start a business

Azevedo, Cornacchione and Casa Nova (2008) carried out a study aiming to identify possible differences in the Accounting courses students identify possible differences in students' perceptions of Accounting and peers students of Management, Actuarial Science, Economics and International Relations. The search identified significant differences regarding the perception the students have on Accounting course to factors such as ambition, propensity to risk, independence, orientation to people, level of study, teamwork, flexibility, level of study, leadership. Concerning to these factors, the external perception of the pairs of students is significantly more negative than the opinion that the Accounting students develop themselves.

Extending studies on the topic, Guerra et al. (2011) investigated the social representations of accounting graduates on their profession. They consider it"a comprehensive profession," see themselves "as an ethical and responsible friend" that "operates in a constantly evolving area, full of challenges and adored by those who practice it" (Guerra et al., 2011, pp. 157). These survey results show the discrepancy between the image that the professional has of himself and that socially constructed and reproduced one.

The prevalence of the Accountant as a professional who develops only technical activities, such as the calculation of income tax, whose training is made in a course focused on mathematics, taxes and computers was also identified by Miranda, Casa Nova and Cornacchione, (2013). They carried out a survey in order to assess the perception and appreciation of the population over the course of Accounting and its labor market, through a web survey answered by 6,642 individuals with complete or incomplete higher education, using social networks.

Azevedo (2010) carried out a survey in order to analyze whether the Accounting professionals are negatively stereotyped, regarding the following characteristics: creativity, dedication to studies, teamwork, communication, leadership, ethics and risk propensity. He applied a photo questionnaire to 1034 and the results showed that people do not perceive the Accounting professionals in a stereotyped way for none of the studied characteristics, but only regarding being male. When reapplying this photo questionnaire, Leal et al. (2014), in Uberlândia-MG, to a sample formed by 1030 individuals (527 students and 503 of external public) found convergent results to those pointed out by Azevedo (2010), regarding the public and the students' perception, which did not confirm any stereotype.

This survey advances in Azevedo's (2010) and Leal et al. (2014) studies, because it investigates the Accounting professional stereotypes in the perception of high school students, in order to confirm or to refute the mentioned studies concerning to the examined variables. To conduct the survey, Azevedo (2010) investigated the variables presented in Table 1 for identifying stereotypes based on the pronouncement of the IFAC (1995). 
Table 1: Variables investigated in Azevedo's survey (2010)

\begin{tabular}{|c|c|c|}
\hline Investigated variables & Description & Source \\
\hline Creativity & $\begin{array}{l}\text { Ability to search, question, create, make } \\
\text { decisions and analyze critically. }\end{array}$ & IFAC (1995) \\
\hline Dedication to studies & $\begin{array}{l}\text { Commitment to learning and } \\
\text { continuous update. }\end{array}$ & IFAC (1995) \\
\hline Teamwork & $\begin{array}{l}\text { Teamwork, ability to interact to } \\
\text { different people and cultures. }\end{array}$ & IFAC (1995) \\
\hline Communication & $\begin{array}{l}\text { Ability to find, get, organize and give } \\
\text { information, Present, discuss, defend } \\
\text { points of view orally or written. }\end{array}$ & IFAC (1995) \\
\hline Leadership & $\begin{array}{l}\text { Ability to lead, motivate, develop } \\
\text { people and resolve conflicts. }\end{array}$ & IFAC (1995) \\
\hline Risk propensity & Take risks and exercise trials & IFAC (1995) \\
\hline Ethic & $\begin{array}{l}\text { Commitment to act with integrity } \\
\text { and objectivity, knowledge of ethical } \\
\text { principles and standards of the } \\
\text { profession; attitude of concern for } \\
\text { social responsibility. }\end{array}$ & IFAC (1995) \\
\hline
\end{tabular}

Source: Azevedo (2010)

These seven variables were analyzed in previous studies to Azevedo's one (2010), although they have not been surveyed together. Concerning to creativity, the results indicated the negative stereotype to Accounting professional (Parker, 2000; Friedman; Lyne, 2001, Dminik \& Felton, 2006, Sugahara \& Boland, 2006; Schlee et al., 2007). Regarding dedication to studies, the Accounting professionals and the students are considered as highly dedicated ones (Hunt et al., 2004, Sugahara \& Boland, 2006, Schlee et al., 2007), but this was not confirmed by Azevedo, Cornachione and Casa Nova (2008), who characterized the Accounting students as less dedicated when compared to other undergraduates in Business area.

Concerning to teamwork, the Accountant image is perceived as inflexible, with little interaction between people and teamwork (Sugahara \& Boland, 2006, Sugahara et al, 2006, Schlee et al, 2007, Jeacle, 2008, Azevedo \& Cornachione, Casa Nova, 2008). The communication skills of the professional Accounting, compared with professionals in other fields, is perceived as less skilled in transmission (Hunt et al, 2004; Sugahara et al, 2006, Schlee et al, 2007, Azevedo, Cornachione \& Casa Nova, 2008).

In relation to leadership, the studies indicated that the accountants are perceived as professionals who have limited capacity for leadership and little initiative (Hunt et al, 2004, Schlee et al, 2007, Azevedo \& Cornachione, Casa Nova, 2008). The propensity to risk is also perceived as a negative image for the accountants, as they are seen as conservative and risk averse (Hunt et al, 2004, Schlee et al, 2007; Azevedo, Cornachione \& Casa Nova, 2008).

And lastly in terms of ethics, the stereotype of the professional Accounting, in some studies, is touted as honest and committed to confidentiality (Friedman \& Lyne, 2001; Dminik \& Felton, 2006). This was somewhat pointed out in the search carried out by Azevedo and Cornacchione Jr. (2012), who did not find evidences of Accounting professionals being negatively stereotyped regarding their professional ethics. Hunt et al. (2004) stated in their survey that the Accounting professional is perceived as not ethical and involved in corporate scandals.

Regarding gender, the Accounting profession has traditionally been associated with the male one (Johl, Jackling \& Wong, 2012). The gender stereotypes disseminated in the traditional perspective of the term are divided in two categories: male and female (Fletcher, 1988). This categorization is due to 
the separation of work into two spheres: public (male) and private (female). This is reinforced by the discourse (social practices, structures and language) that emphasizes the knowledge in a sphere as inappropriate for another, determining the attributes which difference them and define their nature. Male sphere is associated to men's work and responsibility, as a family maintainer. The female sphere is associated with the duties of taking care of home and children.

Morgan (2004) discusses the influence of gender in cultures and in organizations. For him, the traditional organization types were dominated by male values. The male stereotype is traditionally associated to logic emphasis, linear thoughts and action as well as to results concern. On the other hand, the female influence has more possibility to "balance and integrate the analytic rational way of being to values that emphasize more intuitive organic and empathy focused behaviors", considering the stereotype which it is associated to (Morgan, 2004, p. 182).

The male and female stereotypes influence the social representations constructed on people's professional role and, as a consequence, in their leadership. To male stereotype are attributed characteristics such as: logic, rational, dynamic, entrepreneur, strategic, independent, competitive, leader and decision maker. To female stereotype, the following characteristics are attributed: intuitive, emotional, submissive, empathic, spontaneous, maternal, cooperator, supportive and loyal follower. When comparing the male and female stereotypes spread in literature to the variables surveyed by Azevedo (2010), we can identify some correspondence between them (Table 2)

Table 2: Correspondence between gender stereotypes and investigated variables

\begin{tabular}{|l|l|}
\hline \multicolumn{1}{|c|}{ Investigated variables } & \multicolumn{1}{c|}{ Gender stereotype } \\
\hline Creativity & Male - entrepreneur, logic, dynamic \\
\hline Dedication to studies & Female - submissive, loyal follower \\
\hline Teamwork & Female - offers support, cooperative \\
\hline Communication & Female - empathic, spontaneous, intuitive \\
\hline Leadership & Male - leader and decision maker, independent \\
\hline Risk propensity & Male - strategic, logic, rational \\
\hline Ethic & Male - Logic \\
& Female - submissive \\
\hline
\end{tabular}

Source: Azevedo (2010) and Morgan (2004)

Gender stereotypes, when compared to the variables surveyed by Azevedo (2010), indicate a correspondence of female to teamwork, communication, dedication to studies and ethic. Leadership, risk propensity, creativity and ethics correspond to male gender. Although the number of female managers has grown in the last decades, management and leadership are still strongly associated with male characteristics, as shown by several studies (Powell, Butterfield \& Parent, 2002, Edlleston et al, 2006, Loureiro \& Cardoso, 2008). Ethics is described as variable on both the logical aspects (knowledge of standards and principles for action), and emotional (concern with social responsibility), and then allocated as corresponding to both genders. The next section describes the methodological proceedings. 


\section{METHODOLOGY}

This is a quantitative survey in which we tested the following hypothesis, in order to identify and analyze social representations on Accounting professional:

- $\mathrm{H} 1$ :The Accounting professionals are negatively stereotyped in the college applicants' perception concerning to creativity.

- $\mathrm{H} 2$ : The Accounting professionals are negatively stereotyped in the college applicants' perception concerning to dedication to studies.

- H3: The Accounting professionals are negatively stereotyped in the college applicants' perception concerning to teamwork.

- $\mathrm{H} 4$; The Accounting professionals are negatively stereotyped in the college applicants' perception concerning to communication.

- H5: The Accounting professionals are negatively stereotyped in the college applicants' perception concerning to leadership.

- H6: The Accounting professionals are negatively stereotyped in the college applicants' perception concerning to risk propensity.

- $\mathrm{H7}$ : The Accounting professionals are negatively stereotyped in the college applicants' perception concerning to ethics.

- H8: The Accounting professionals are negatively stereotyped in the college applicants' perception as being male.

To collect the information, we used a photo questionnaire (Figure 1) which was tested and validated by Azevedo (2010). According to Martins and Theóphilo (2007), surveys can be employed in order to identify relationships between variables and we did it in this work. 


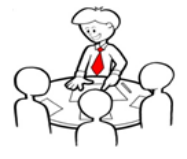

M-Teamwork POS

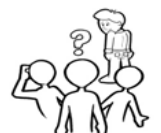

M-Leadership

NEG

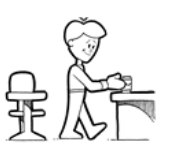

M-Creativity NEG

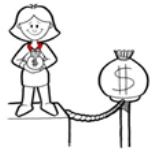

F-Risk Propensity NEG

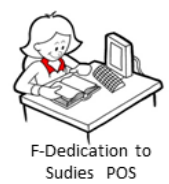



M-Teamwork NEG

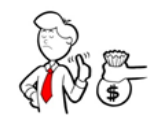

M-Ethics POS

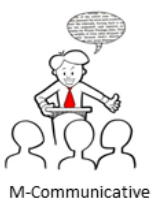

POS
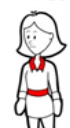

F-Neutral

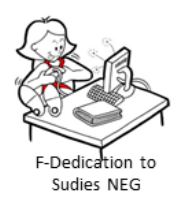

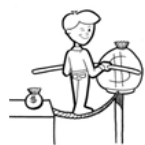

M-Risk Propensity

POS
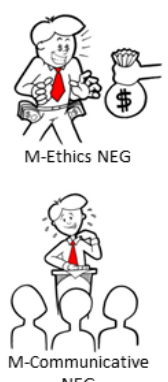

NEG

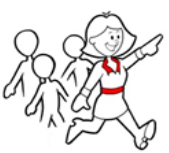

F-Leadership POS



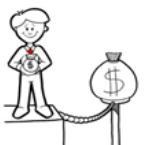

M-Risk Propensity NEG

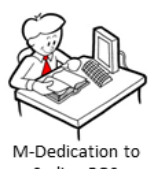

Sudies POS
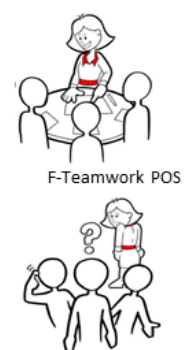

F-Leadership NEG

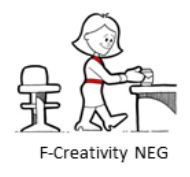



M-Neutral

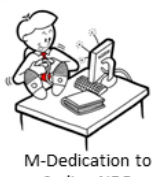

Sudies NEG
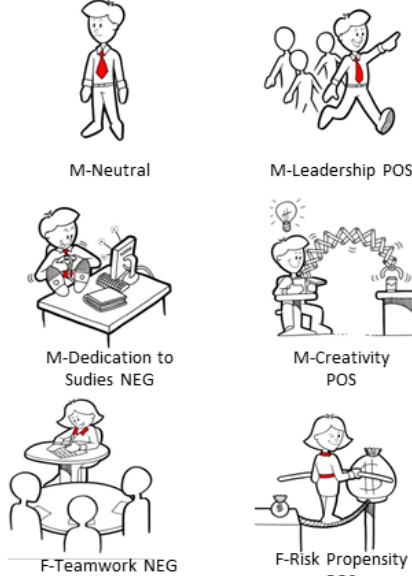

M-Leadership POS
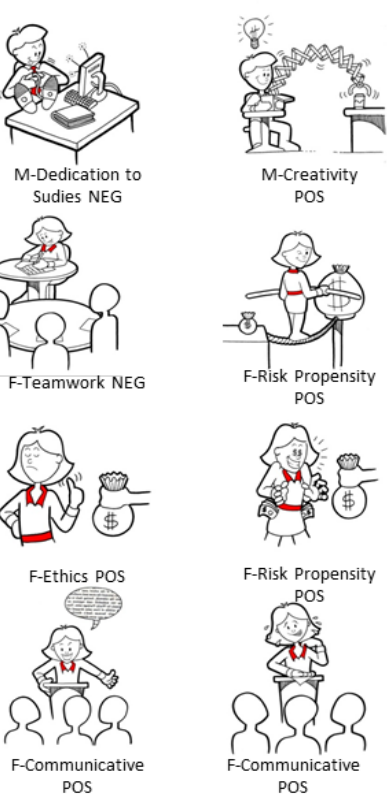

POS

Legend: M (Male); F (Female); POS (positive) NEG (Negative).

Source: Azevedo (2010). Images elaborated by the artist Alexandre Ostan

To test the hypothesis of this search, the figures with negative characteristics were identified with -1 value; those with positive characteristics received 1 value and the neutral ones, zero. The sample averages were statistically tested by being or not different from zero.

We collected 822 answers; however we excluded 15 ones, because they had no answers to the investigated variables. The sample in this study is a not probabilistic one, composed by 807 students in nine public schools of high school in Uberlândia-MG. This sample corresponds to $3.22 \%$ of student population in this level, which is composed of 25.049 students enrolled in high school, according to The Minas Gerais State Education Secretary. The data were collected from 2012 September 3rd and November 10th, during the visits to the schools. The students' participation was voluntary and data collection was done in the classroom, with the authorization of the staff and the teachers.

To test the hypothesis, we carried out tests using a statistical software, adopting significance level at $0.05(a=0.05)$. We present the results in the next section.

\section{5. (RE)CONSTRUCTING THE ACCOUNTING PROFESSION STEREOTYPE}

This section presents the results of the survey. We begin with descriptive aspects and afterwards we discuss the social representations of the studied students on Accounting professional. 


\subsection{DESCRIPTIVE ASPECTS OF THE RESULTS}

The sample had 476 female (59\%) and 320 (39.7\%) of the male. Eleven respondents (1.4\%) did not inform their gender. Regarding age, 89.6 of the respondents are aged below 18 years.

The research focused, initially, students who were enrolled in third year, because they were in the moment to choose their Undergraduate course. However, 73 respondents (9.1\%) were enrolled in the first or in the second year of the course, and the others (90.9\% were e rolled in the third year). We considered all of them. Regarding the class period, $76 \%$ of respondents were studying in the morning $17 \%$, in the afternoon, and $7 \%$ on evening course.

When asked about professional choice, 43 students (5.3\%) responded that they intended to attend Accounting course; 686 (85\%) had other choices and 78 college applicants (9.7\%) still were undecided because they did not report any course. The percentage of students who opted for accounting course is quite close to the average of seats held by students in Accounting in higher education in Brazil (4.2\%) as shown in the Higher Education Census (2010).

Table 3 presents the number of participants, the average and pattern deviation for each variable investigated in this survey. As both Azevedo (2010) and Leal et al. (2014) used the same instrument (photo questionnaire) and investigated the same variables, when possible, comparisons between the results are made.

Table 3: Statistic description of the variables

\begin{tabular}{|c|c|c|c|}
\hline Categories & $\mathrm{N}$ & Average & Pattern Deviation \\
\hline Creativity & 799 & 0.32 & 0.835 \\
\hline Dedication to studies & 797 & 0.82 & 0.475 \\
\hline Teamwork & 795 & 0.71 & 0.646 \\
\hline Communication & 793 & 0.68 & 0.623 \\
\hline Leadership & 803 & 0.78 & 0.491 \\
\hline Risk propensity & 800 & 0.27 & 0.863 \\
\hline Ethic & 802 & 0.25 & 0.754 \\
\hline
\end{tabular}

Source: Research Data

The averages of all variables were positive, which means that the college applicants' representations on accounting professionals were positive for all the analyzed variables. This result corroborates the findings of research by Leal et al. (2014) and also the findings of Azevedo (2010) in research conducted by the public perception. It is worth mentioning that the averages calculated with the high school students were very close to the averages calculated by the public perception in the study carried out by Leal et al. (2014) but were higher than those calculated with accounting students in five of the seven variables investigated. This means that the students obtained higher averages of 0.29 and 0.40 , respectively, only for the variables "Propensity to risk" and "Ethics". In this respect, it is important to mention that the high school students were respondents who reported the lowest average for the variable "Ethics". This variable is still the one with the lowest average of all investigated (Table 1). Although it was a positive result (0.25), the fact that the lowest average shows that "ethics" does not seem to be one of the attributes that, socially, represents the image of the accountant for the college applicants. 


\subsection{SOCIAL REPRESENTATIONS OF ACCOUNTING PROFESSIONAL}

The analysis of the confidence intervals (assuming 95\%) and t-tests show significant differences for all variables, as shown in Table 2. Thus, $\mathrm{H1}, \mathrm{H2} 2 \mathrm{H3}, \mathrm{H} 4, \mathrm{H} 5, \mathrm{H} 6$ and $\mathrm{H} 7$ hypotheses were rejected.

On the one hand, these findings are convergent to the results reported by Azevedo (2010) and also by Leal et al. (2014), since, in these studies; all seven hypotheses were also rejected. On the other hand, the results are contrary to the findings of other studies investigating the image of the accountant (Parker, 2000; Friedman; Lyne 2001; Dminik; Felton, 2006; Sugahara; Boland, 2006; Schlee et al, 2007).

Table 4: TTest on average differences for the analyzed categories

\begin{tabular}{|l|c|c|c|c|c|c|}
\hline \multicolumn{1}{|c|}{ Categories } & $\mathrm{N}$ & Statístical t & $\begin{array}{c}\text { Sig. } \\
\text { (bicaudal) }\end{array}$ & $\begin{array}{c}\text { Average } \\
\text { difference }\end{array}$ & \multicolumn{2}{c|}{$\begin{array}{c}\text { Confidence interval: } \\
\text { Lower Higher }\end{array}$} \\
\hline Creativity & 798 & 10.967 & 0.000 & 0.324 & 0.27 & 0.38 \\
\hline Dedication to studies & 796 & 49.020 & 0.000 & 0.824 & 0.79 & 0.86 \\
\hline Teamwork & 794 & 31.089 & 0.000 & 0.712 & 0.67 & 0.76 \\
\hline Communication & 792 & 30.962 & 0.000 & 0.685 & 0.64 & 0.73 \\
\hline Leadership & 802 & 45.055 & 0.000 & 0.781 & 0.75 & 0.81 \\
\hline Risk propensity & 799 & 8.807 & 0.000 & 0.269 & 0.21 & 0.33 \\
\hline Ethic & 801 & 9.275 & 0.000 & 0.247 & 0.19 & 0.30 \\
\hline
\end{tabular}

Source: Research Data

Therefore, we cannot affirm that Accounting professionals are negatively stereotyped in the college applicants' perception for the variables creativity, dedication to studies, teamwork, communication, leadership, ethics and risk propensity, according to the study sample, but rather that the image is positive and significantly different from zero for all of them.

These results may be related to numerous changes in the Accounting area in recent years, as previously mentioned, reinforcing the idea that emerges a new profile for the profession in this new context. Social representations depend on the social and historical context (Spink, 1993), so the contextual changes are reflected in the breakdown of traditional stereotyping. As Moscovici (1978) observes, the representations are not reducible to opinions of individuals, but rather a network of images

\subsection{MAN ACCOUNTANT AND WOMAN ACCOUNTANT, NOT ONLY MAN AC- COUNTANT}

To analyze gender stereotype, $\mathrm{H} 8$ hypothesis, we used Minitab@ software 14th version, applying the Chi-Square test (X2). This test allowed us to verify the statistical significance between distributions of two or more scaling nominal variables in a cross-tabulation, in order to determine whether there is or not any association between the variables. We measured the probability of the differences found in two sample groups have been due to chance, assuming that there are no differences between these groups in the population (Hair et al., 2010).

For the application of the chi-square (X2), the responses were reclassified using the number 1 for male designs and the number 0 , for feminine designs. Thus, it was possible to test whether respondents 
associate the image of the Accounting profession to males or females (eighth hypothesis), as shown in Table 5.

Table 5: $X^{2}$ test for perception by gender / College Applicants

\begin{tabular}{|c|c|c|c|c|c|}
\hline Categories & Gender & Observed & Waited & Chi-square & Sig. \\
\hline \multirow{2}{*}{ Creativity } & Male & 406 & 399.5 & \multirow{2}{*}{0.2115} & \multirow{2}{*}{0.646} \\
\hline & Female & 393 & 399.5 & & \\
\hline \multirow{2}{*}{ Dedication to studies } & Male & 421 & 398.5 & \multirow{2}{*}{2.540} & \multirow{2}{*}{0.111} \\
\hline & Female & 376 & 398.5 & & \\
\hline \multirow{2}{*}{ Teamwork } & Male & 400 & 397.5 & \multirow{2}{*}{0.031} & \multirow{2}{*}{0.859} \\
\hline & Female & 395 & 397.5 & & \\
\hline \multirow{2}{*}{ Communication } & Male & 408 & 396.5 & \multirow{2}{*}{0.667} & \multirow{2}{*}{0.414} \\
\hline & Female & 385 & 396.5 & & \\
\hline \multirow{2}{*}{ Leadership } & Male & 360 & 401.5 & \multirow{2}{*}{8.579} & \multirow{2}{*}{0.003} \\
\hline & Female & 443 & 401.5 & & \\
\hline \multirow{2}{*}{ Risk propensity } & Male & 377 & 400.0 & \multirow{2}{*}{2.645} & \multirow{2}{*}{0.104} \\
\hline & Female & 423 & 400.0 & & \\
\hline \multirow{2}{*}{ Ethics } & Male & 377 & 401.0 & \multirow{2}{*}{2.8721} & \multirow{2}{*}{0.090} \\
\hline & Female & 425 & 401.0 & & \\
\hline
\end{tabular}

Source: Survey data

The tests revealed that in the social representation of high school students, there are stereotype for "leadership" variable associated with male gender (Table 5) This implies that regarding the ability to lead people, the students perceive it as related to male Accounting professionals. Avezedo (2010) and Leal et al (2014) also achieved gender stereotypes (men) to the leadership variable with public perception, which meets the analyzed literature (Morgan, 2004).

This similarity with the results of Azevedo (2010) and Leal et al. (2012) on the gender stereotype for the variable leadership may represent a relationship with the socio-historical and geographical context in which the research was applied, and the method used. However, it should be considered that the target audience is different, once in this research it concerns to high school students, unlike others which aimed at undergraduate students. Dimmik \& Felton (2006) and Carnegie \& Napier (2010) also identified in studies conducted in the North American context and applying other methods, that the studied public presents a perception that accountants/accounting professionals are male.

When analyzing the gender issue, changes in social representations of the accountancy profession are evident. Although Azevedo's study has found evidence that Accounting professionals are more perceived as being male, the relationship is not statistically significant for the variables "teamwork" and "communication". According to the literature on gender, these two variables are associated with the female gender (Morgan, 2004), which implies changes as the stereotype of the professional Accounting traditionally associated with being male.

These characteristics are appropriate for the current context of the profession; the demand for a flexible professional, able to play multiple roles and skills to deal with complex situations and contexts of uncertainty grows increasingly. Moreover, these characteristics move away from the predominant profile of the accountant as purely technical or professional bookkeepers (Miranda, Casa Nova \& Cornachione, 2013, Pires, Ott \& Damacena, 2009), as in the beginning of the creation of the profession. 
This modification is congruent to the changes in the university environment. Women are now the majority in most of the upper-level courses in Brazil (Brazil, 2008). In 2008, the Accounting course presented a percentage of $54.8 \%$ of women. These changes have occurred for some time: in 1991, the percentage of female students in the Accounting course was approximately $44 \%$, reaching $50 \%$ in 2004 and 53\% in 2008, showing a reversal in prevailing gender in Accounting. This trend also occurs in other professions in Brazil, as the females occupied in 2008, 54.6\% of enrollments in classroom teaching (Miranda, 2011). In 2010, the percentage of classroom and distance enrollments of females was 57\%, as shown by the National Higher Education Census 2010.

\section{CONCLUSIONS}

Based on the understanding that a profession stereotype is a fruit of social representations and can influence people in several ways, including the career choice on entering Higher Education, this study aimed to identify social representations of college applicants on the stereotype of accounting professional, in order to compare them to the widespread over time stereotyping. Many studies show that the typical stereotype of the Accounting profession portrayed cold, impersonal and indifferent people, characterized predominantly by male, conservative and inflexible individuals.

This search achieved the objective of identifying a possible rupture in the Accounting professional stereotype, from the social representations of the surveyed college applicants. These social representations are very significant when choosing a career, because these young man and women constitute a new generation whose worldview differs from that of previous seasons. We suppose, then, that they do a contemporary world reading that it is possible to be contrasted to previous surveys.

The results showed that the accounting professionals are not negatively stereotyped by the college applicants regarding the variables "creativity", "dedication to studies", "teamwork", "communication", "leadership", "risk propensity" and "ethics". In contrast, the image is positive and significantly different from zero for all of them. This finding corroborates the findings of a few recent studies in Brazil (Azevedo, Cornachione \& Casa Nova, 2008, Miranda, Casa Nova \& Cornachione, 2013, Azevedo, 2010, Leal et al, 2014). However, it contradicts other studies carried out on the Accountant image was negatively evidenced (Friedman \& Lyne, 2001, Hunt et al, 2004, Jeacle, 2008, Carnegei \& Napier, 2010).

This modification in social representations, identified through the changes in the results of searches carried out at the beginning of this century on accounting professionals points to the emergence of a new professional profile. This is consistent to the deep changes in Accounting itself, in market and in wider society, and this fact is even confirmed by the phenomenon of globalization and its effects on the Accounting framework (international standards).

When we separate the samples for specific analysis of the question "gender", yet, we face with negative stereotype for the "leadership" variable". College applicants, understood here as a new generation, realize that leadership in the Accounting field is associated with the male gender. However, the results show a significant change in the social representations on the part of the new and previous generations. In studies conducted by Azevedo (2010) and Leal et. al. (2014) with public perception (with different aged interviewed in public space), the stereotype of gender (male) reached all seven variables (creativity, dedication to studies, teamwork, communication, leadership, propensity to risk and ethics). 
Associating leadership to male gender is not a peculiarity of accounting field, as several other contemporary studies continue to point this association (Loureiro \& Cardoso, 2008). Anyhow, judging from the space that the female gender has gained over time in the Academy, it is expected that in some years the stereotype of the profession as a male attribute will be overcome.

Career choice is a complex process to young people who end High School, because they face a conflict situation which involves anxiety and doubts, among other feelings in this phase of their lives. When choosing a career, the young men and women face with a multiplicity of factors involved in that decision, including his personal recognition, their wishes and their participation in society (Sparta \& Gomes, 2005)

This search has practical and theoretic implications. Regarding the practical ones, this study contributes to knowledge on Accounting professional, because it indicates a possible break in the traditional stereotype mainly regarding gender, which can influence the individual career choice as well the treatment itself dispensed to them by the labor market. Concerning to the theoretical implications, this survey contributes to the reflection on social representations and its impacts on the Accounting professional's identity constructing and actuation.

The main limitation was the sample being not probabilistic and exclusive to the city of Uberlandia. It cannot be generalized to other contexts. In this sense, new possibilities for research are identified: research addressing other Brazilian regions may help in understanding the issue and raise other relevant aspects of social representations on the Accounting professionals; more detailed studies on gender issues, providing better understanding of the changes highlighted in this research and the educational statistics; researches in other contexts to investigate the construction of professional identity; studies that compare the professional image the professional has of himself with that socially constructed one; and researches that investigate the possible impacts of the adoption of international Accounting standards in the image of this profession in Brazil.

What can grasp it is that these changes can be reflections of social, historical and geographical context, for as Spink (1993), social representations are manifestations thus determined. In this case, the greater inclusion of women in the university environment in general and, in particular, in Accounting course, was due to changes occurred in the socio-historical context and also geographical, which worsened the change of the associated Accounting professionals' stereotype.

\section{REFERENCES}

Ainlay, S. C., Bercker, G. \& Colman, L. M. A. (1986). Stigma reconsidered. In: Ainlay, S. C., Becker, G. \& Colman, L. M. A. (Ed), The Dilemma of Difference. New York: Plenum.

Albu, N., Albu, C. N., Girbina, M.M. \& Sandu, M.I. (2011). A Framework for the Analysis of the Stereotypes in Accounting. World Academy of Science, Engineering and Technology, 53, pp.874-878.

Azevedo, R. F. L., Cornachione Junior, E. B. \& Casa Nova, S. P. De C. (2008). A percepção dos estudantes sobre o curso e o perfil dos estudantes de contabilidade: uma análise comparativa das percepções e estereotipagem. In: Congresso USP de Contabilidade de Controladoria, 8, São Paulo. Anais... São Paulo: USP. 
Azevedo, R. F. L. (2010). Percepção publica sobre os contadores:"Bem ou mal na foto"? 2010. 103f. Dissertação (Mestrado em Ciências Contábeis). Universidade de São Paulo, São Paulo.

Azevedo, R. F. L. \& Cornachione, E. B. (2012). Ética Profissional Contábil: uma Análise Visual da Percepção Pública. Revista de Educação e Pesquisa em Contabilidade, 6 (1), art. 2, pp. 19-37.

Berger, P. L., Luckmann, T. (1987). A construção social da realidade. Petrópolis: Vozes.

Carnegie, G. D., Napier, C. J. (2010). Traditional accountants and business professionals: Portraying the Accounting profession after Enron. Accounting, Organizations and Society, v. 35, pp. 360-376.

Conselho Federal De Contabilidade (CFC). Perfil do Contabilista Brasileiro (2009). Disponível em: http:// www.crcrs.org.br/arquivos/livros/livro_CFC_perfil2009.pdf. Acesso em 06 set. 2012.

Decoster, D. T., Rhode, J. G. (1971). The Accountant's Stereotype: Real or Imagined, Deserved or Unwarranted. The Accounting Review, 46 (4), pp. 651-664.

Dias, G. M. (2003). Representações sociais que contribuem para a construção do imaginário coletivo sobre o contador e a contabilidade: um estudo empírico. 2003. Dissertação (Mestrado em Ciências Contábeis). Faculdade de Economia, Administração e Contabilidade, USP, SP.

Dminik, T., Felton, S. (2006). Accountant stereotypes in movies distributed in North America in the twentieth century. Accounting Organizations and Society, 31 (2), pp. 129-155.

Eddleston, K. A., Veiga, J. F., Powell, G. N. (2006). Explaining sex differences in managerial satisfier preferences: The role of gender self-schema. Journal of Applied Psychology, 91 (2), pp. 437-445.

Fletcher, J. (1998). Relational Practice: A feminist reconstruction of work. Journal of Management Inquiry, 7, pp. 163-186.

Friedman, A. L., Lyne, S. R. (2001). The beancounter stereotype: towards a general model of stereotype generation. Critical Perspectives on Accounting, 12 (4), pp. 423-451.

Gil, A.C. (2002). Métodos e técnicas de pesquisa social. São Paulo: Atlas.

Goffman, E. (1998). Estigma: notas sobre a manipulação da identidade deteriorada. Rio de Janeiro: Guanabara.

Grize, J. B. (2001). Lógica natural e representações sociais. In: Jodelet, D. (Ed.). As representações sociais. Rio de Janeiro: UERJ, pp. 123-137. 
Guerra, G. C. M., Shinzaki, K., Ichikawa, E. Y. \& Sachuk, M. I. (2011). A representação social da profissão de contador na Perspectiva dos profissionais da contabilidade. Revista de Contabilidade e Organizações, 5 (12), pp. 157-171.

Hair, J. F., Jr, Wolfinbarger, M., Ortinau, D.J. \& Bush, R. P. (2010). Fundamentos de Pesquisa de Marketing. Porto Alegre: Bookman.

Hall, S. (1997). The spectable of the 'other'. In: S. Hall (Ed.). Representation. Culture representations and signifying practices. London: Sag Publications, pp. 223-290.

Hunt, S. C., Falgiani, A. A. \& Intrieri, R. C. (2004). The Nature and Origins of Students' Perceptions of Accountants. Journal of Education for Business, 79 (3), pp. 142-148.

Instituto Nacional De Estudos E Pesquisas Educacionais Anísio Teixeira (INEP). Censo da Educação Superior (2010): análise crítica dos resultados para a tomada de decisões estratégicas. Disponível em: <http://www.abmes.org.br/abmes/public/arquivos/documentos/Christyne_e_Renan.pdf $>$. Acesso em: 13 ago. 2012.

Jeacle, I. (2008). Beyond the boring grey: The construction of the colorful accountant. Critical Perspectives on Accounting, 19, pp.1296-1320.

Jodelet, D. (2001). Representações sociais: um domínio em expansão. In: JODELET, D. (org). As representações sociais. Rio de Janeiro: EdUERJ.

Johl, S., Jackling, B. \& And Wong, G. (2012). Ethical decision-making of accounting students: evidence from an Australian setting. Journal of business ethics education, 9 (1), pp. 51-78.

Leal, E. A., Miranda, G. J., Araújo, T. S. \& Borges, L. F. M. (2014). Estereótipos na Profissão Contábil. Contabilidade, Gestão e Governança, 17 (1), pp. 134-153.

Loureiro, P., Cardoso, C. C. (2008). O gênero e o estereótipo na gestão. Revista de Estudos Politécnicos, 6 (10), pp. 221-238.

Marion, J. C. (2009). Contabilidade Empresarial. 15 ed. São Paulo: Atlas.

Martins, G. de A., Theóphilo, C. R. (2007). Metodologia da Investigação Científica para Ciências Sociais Aplicadas. São Paulo: Atlas.

Martins, E., Diniz, J. A. \& Miranda, G. J. (2012). Análise Avançada das Demonstrações Contábeis. São Paulo: Atlas. 
Miranda, G. J. (2011). Relações entre as qualificações do professor e o desempenho discente nos cursos de graduação em Contabilidade no Brasil. São Paulo, 2011. Tese (Doutorado em Ciências Contábeis) Programa de Pós-Graduação em Ciências Contábeis, Departamento de Contabilidade e Atuária, FEA/ USP, São Paulo.

Miranda C. S., Araujo, A. M. P. \& Miranda, R. A. de M. (2012). Percepções sobre o Ensino Superior de Contabilidade e o Mercado de Trabalho dos Contadores: Uma Avaliação da População com Curso Superior Completo ou em Curso. In: Congresso USP de Controladora e Contabilidade, 12, São Paulo, Anais... São Paulo.

Miranda, G. J., Casa Nova, S. P. de C. \& Cornacchione Jr, E. B. (2013). Ao Mestre com Carinho: Relações entre as Qualificações Docentes e o Desempenho Discente em Contabilidade. Revista Brasileira de Gestão e Negócios, 15 (48), pp. 462-481.

Morgan, G. (2004). Imagens da Organização. São Paulo: Atlas.

Moscovici, S. (2004). Representações sociais: investigações em psicologia social. Petrópolis: Vozes.

Moscovici, S. (1978). A representação social da psicanálise. Rio de Janeiro: Zahar.

Uol. (2012). Pesquisa lista as dez profissões que tiveram os maiores aumentos salariais em 2012. (2012)<http://noticias.uol.com.br/empregos/ultimas-noticias/2013/02/07/pesquisa-lista-as-dez-profissoes-que-tiveram-os-maiores-aumentos-salariais-em-2012.jhtm>. Acesso em: 08 fev. 2012.

Parker, I. (2000). Goodbye, number cruncher! Australian CPA, 77 (2), pp.50-52.

Peleias, I. R., Bacci, J. (2004). Pequena cronologia do desenvolvimento contábil no Brasil: Os primeiros pensadores, a padronização contábil e os congressos brasileiros de contabilidade. Revista Administração On Line, 5 (3), pp.39-54.

Phelan, J., Link, B. \& Dovidio, J. (2008). Stigma and prejudice: one animal or two? Soc. Sci, Med, 67, pp. 358-367.

Pires, C. B., Ott, E. \& Damacena, C. (2009). "Guarda-Livros" ou “Parceiros de Negócios"? Uma Análise do Perfil Profissional Requerido pelo Mercado de Trabalho para Contadores na Região Metropolitana de Porto Alegre (RMPA). Contabilidade Vista \& Revista, 20 (3), pp. 157-187.

Powell, G. N., Butterfield, D. A. Parent, J. D. (2002). Gender and managerial stereotypes: Have the times changed? Journal of Management, 28 (2), pp. 177-193.

Ramos, A. G., Lima, E. S. (1996). O secundarista e o processo de escolha da profissão. Revista Brasileira de Estudos Pedagógicos, 77, pp.191-219. 
Schlee, R., Curren, M., Harich, K. \& Kiesler, T. (2007). Perception bias among undergraduate business students by major. Journal of Education for Business, 82 (3), pp.169-177.

Sparta; M., Gomes, W.B. (2005). Importância atribuída ao ingresso na educação superior por alunos do ensino médio. Revista Brasileira de Orientação Profissional, 6 (2).

Spink, M. J. P. (1993). O conceito de representações sociais em Psicologia Social. Cad. Saúde Públ., Rio de Janeiro, 9 (3), pp. 300-308.

Sugahara, S., Boland, G. (2006). Perceptions of the certified public accountants by Accounting and mon-Accounting tertiary students in Japan. Asian Review of Accounting, 14 (1-2), pp. 149-167.

Wells, P. (2010). Those persistent Accounting stereotypes: Why are they so resistant to change. AFAANZ Conference. Disponível em: <http://www.afaanz.org/openconf/2010/modules/request.phpmodule=oc_proceedings\&action=view.php\&a=Accept+as+Paper\&id=134>Acesso em: 3 dez. 2012. 